\title{
NUTRITIONAL STUDIES ON PARTIAL AND TOTAL REPLACEMENT OF SOYBEAN MEAL WITH GUAR MEAL (CYAMOPSIS TETRAGONOLOBA (L.) IN NILE TILAPIA (OREOCHROMISNILOTICUS) DIETS
}

\author{
Eman M. Labib ${ }^{1}$; Faiza A. Salama ${ }^{1}$; Hayam D. Tonsy ${ }^{1}$; and M. A. Zaki ${ }^{2}$ \\ ${ }^{1}$ Animal Production Research Institute, Utilization By-Products Department, Agriculture Research \\ Center, Dokki, Giza, Egypt. \\ ${ }^{2}$ Faculty of Agriculture, Alexandria University. Aflaton St., El-Shatby Alexandria, Egypt.
}

(Received 1/10/2015, Accepted 29/11/2015)

\section{SUMMARY}

$\mathrm{T}$ The main objective of this study was to evaluate the effect of partial and total $(0 \%, 25 \%$, $50 \%, 75 \%$, and $100 \%$ ) replacement of soy bean meal (SBM) protein by guar meal (Cyamopsis tetragonoloba) (GM) protein in commercial diets on water quality, ,survival rate \%, growth performance, feed utilization, whole body composition, physiological parameters and economic efficiency of Nile tilapia, Oreochromis niloticus fry. Fish fry with an average initial weight of $0.825 \pm 0.01 \mathrm{~g} /$ fish were stocked at a rate of $10 \mathrm{fish} /$ aquarium (100L water) for 84 days experimental period. Five experimental diets were formulated to be isocaloric (454.34 kcal GEl/100 g dry matter, DM) and isonitrogenous (30.25\% crude protein, CP \%). The results of this study revealed that, the highest $(\mathrm{P} \leq 0.01)$ final weights, specific growth rate, protein and nutrient utilization were recorded by GM 25 and 50\% groups followed by the control group and the GM 75 and $100 \%$ groups, respectively. Therefore, these results suggest that the replacement of 25 and 50\% of SBM by GM had a significant increase on fish growth performance (final body weight, average body weight and Specific growth rate \%), feed and nutrient utilization respectively, however replacing of the higher GM levels (75 or 100\%) significantly $(\mathrm{P} \leq 0.01)$ reduced them. The group fed on 50\% GM exhibited comparable growth performance to those fed SBM based diet. Carcass CP\% was significantly $(\mathrm{P} \leq 0.01)$ increased with the increase of dietary GM up to $50 \%$ and decreased with $75 \%$ and $100 \%$ levels. Dietary GM levels does not show any significant effects on carcass ether extract (EE \%). Increasing GM up to100\% increased carcass ash content significantly $(\mathrm{P} \leq 0.01)$ while energy content $(\mathrm{EC})$ values were decreased. Hematocrit and hemoglobin values (hematological parameters) were almost decreased proportionally with increasing the dietary GM with the largest declines in groups fed on 75-100\% GM levels. Values of serum transaminases (aspartate aminotransferase, AST and alanine aminotransferase, ALT) were almost increased with the increase in GM level as a substitute for SBM in Nile tilapia diets. Therefore, these results suggest that up to $50 \%$ of soy bean meal protein can be replaced by guar meal protein in mono sex Nile tilapia diets without any adverse effect on growth performance and feed utilization.

Keywords: Nile tilapia, (Oreochromis niloticus), growth performance, Guar meal.

\section{INTRODUCTION}

Fish nutrition consist a major part of the production costs. Protein is the more expensive dietary nutrient item especially with the using of fish meal as the sole protein source.Therefore, fish nutritionist's paid a high interest in their experiments to replace fish meal partly or completely with plant protein sources in fish diets (Salze et al., 2010; Zhou and Yue, 2010). Utilization of plant protein may be less challenging for omnivorous fish species (Hardy, 2010). Soy bean (SB) has a fair amino acid profile to be used in aqua feed; however, it is highly useful in human food (Van der Ingh et al., 1991). Replacing soy protein (SP) with a low price alternative plant protein sources without any negative impact on nutritional 
and physical quality of fish feed may reduce costs and helps to global food production. Numerous studies have evaluated the possibility of utilization of cheaper protein resources such as industrial secondary products in aqua feeds (Francis et al., 2001; Slawski et al., 2013; Collins et al., 2013).

Guar meal (GM) is the main by-product of guar gum production. It is a relatively inexpensive high protein meal source as a mixture of germs and hulls at an approximate ratio of $25 \%$ germ to $75 \%$ hull (Lee et al., 2002) results from combinations of two fractions, the germ and hull contain approximately 60 and $35 \%$ protein, respectively (Conner, 2002). It is an interesting feedstuff due to its relatively high protein content, (40-45 \% on DM basis) for the regular meal (Gowda et al., 2004). Mathur and Mathur, (1989) reported that GM is comparable to soybean meal (SBM) in terms of its nutritional contents. However, GM contains other types of anti-nutritional factors: trypsin inhibitors, saponin, haemagglutinins, hydrocyanic acid and polyphenols (Gutierrez et al., 2007).

However, anti-trypsin activity was found to be lower than in heat-treated SBM and therefore not the main cause of anti nutritional effects in poultry (Lee et al., 2004). The large saponin content of guar seeds (up to $13 \% \mathrm{DM}$ ) could have both anti-nutritionals effect and a positive antimicrobial activity (Hassan et al., 2010).Guar meal can replace up to $50 \%$ of fishmeal protein in common carp (Cyprinus carpio) fingerlings diets, however its higher rates of inclusion decreased protein, lipid and protein digestibility (El-Saidy et al., 2005). Also, milled guar seeds could successfully replace up to $50 \%$ of fish meal in the diets of Nile tilapia, without adverse effects on feed utilization and growth, though more trials are necessary to investigate the long-term effects of such diets (Al-Hafedh and Siddiqui, 1998). On the other hand, milled and pelleted guar seeds, raw or autoclaved, were fed directly to mrigal fingerlings (Cirrhinus mrigala). Feeding raw and autoclaved guar resulted in lower survival, weight gain and carcass protein, fat and energy content than for the fish fed soybeans, mung beans and cowpeas (Garg et al., 2002).Therefore, this study has carried out to determine the feasibility of this guar meal (Cyamopsis tetragonoloba) protein as a possible replacement for soy bean meal protein in practical diets for fry mono sex male Nile tilapia, Oreochromis niloticus (L.).

\section{MATERIAL AND METHODS}

\section{Water quality:}

Water temperature and dissolved oxygen were measured every other day using an YSI Model 58 oxygen meter (YSI Industries, Yellow Spring, OH, USA). Total ammonia, nitrate were measured weekly using spectrophotometer (Spectronic 601, Milton Roy Company, a Diego, CA, USA). Alkalinity was monitored twice weekly using the titration methods of Golterman,(1977). The $\mathrm{pH}$ was monitored twice weekly using an electronic $\mathrm{pH}$ meter ( $\mathrm{pH}$ pen, Fisher Scientific, Cincinnati, OH, USA). During the 12week feeding trial, the water quality parameter averaged $( \pm \mathrm{SD})$ : temperature $28.4 \pm 0.4$; dissolved oxygen $4.7 \pm 0.3$; pH 7.8 \pm .3 ; ammonia $0.021 \pm 0.01 \mathrm{mg} \mathrm{L}^{-1}$; nitrite $0.029 \pm 0.17 \mathrm{mg} \mathrm{L}^{-1}$; nitrate $0.9 \pm 0.3 \mathrm{mg} \mathrm{L}^{-1}$ and alkalinity $178 \pm 3.5 \mathrm{mg} \mathrm{L}^{-1}$.

\section{Fish and culture facility:}

This study has been carried out at the Wet Fish Laboratory, Department of Animal and Fish Production, Faculty of Agriculture, Alexandria University. The experimental work was designed to evaluate the effect of partial and total $(0 \%, 25 \%, 50 \%, 75 \%$, and $100 \%)$ replacement of soy bean meal (SBM) protein by guar meal (Cyamopsis tetragonoloba) (GM) protein in commercial diets on water quality, survival rate $\%$, growth performance, feed utilization, whole body composition, physiological parameters and economic efficiency of Nile tilapia, (Oreochromis niloticus) fry. Fish were acclimated in the experimental lap for 20 days before starting the experiments. Fish fry with an average initial body weight of $0.825 \pm 0.01 \mathrm{~g} / \mathrm{fish}$ were placed randomly in fifteen glass aquaria with dimensions of $100 \times 40 \times 30 \mathrm{~cm}$ each and $100 \mathrm{~L}$ volume of water /aquarium. Each aquarium was stocked with ten fingerlings of (O. niloticus) and three replicates for each treatment were used in the present study.

\section{Experimental diets:}

Five isonitrogenous and isocaloric experimental diets containing approximately $30.25 \%$ crude protein and $454.34 \mathrm{kcal}$ gross energy/100g diets were formulated. D1 (control); containing $9.91 \%$ soy bean meal (SBM) protein was formulated to be a high-quality commercial tilapia fish diet. The other four diets (D2, D3, D4 and D5) contained 25,50, 75 and 100\% guar meal (GM) protein in replacement of soybean meal protein (Table 1).Each ingredient was ground and thoroughly mixed with the other dietary ingredients, 
vitamins and minerals mixtures. A few drops of oil was added at the same time of mixing with warm water $\left(45^{\circ} \mathrm{C}\right)$ which was slowly added until the diets began to clump. Diets were processed by a California pellet mill machine and dried for $48 \mathrm{hrs}$ at $70^{\circ} \mathrm{C}$ in a drying oven. The pellet size was $0.6 \mathrm{~mm}$ in diameter and $2 \mathrm{~mm}$ in length. Fish in each aquarium were fed two times daily (six days a week) at a rate of $5 \%$ of body weight for 84 days.

Table (1). Feed ingredients and proximate analysis ( $\mathrm{g} 100 \mathrm{~g}-1)$ of experimental diets.

\begin{tabular}{|c|c|c|c|c|c|}
\hline \multirow{2}{*}{ Item } & \multicolumn{5}{|c|}{ Experimental diets $^{1}$} \\
\hline & D1 & D2 & D3 & D4 & D5 \\
\hline \multicolumn{6}{|l|}{ Ingredient $\left({\left.\mathrm{g} 100 \mathrm{~g}^{-1}\right)}\right.$} \\
\hline Fish meal (FM) $(65 \%)$ & 23 & 23 & 23 & 23 & 23 \\
\hline Soybean meal (SBM)(43.12\%) & 23 & 17.3 & 11.5 & 5.75 & - \\
\hline Guar meal (GM) & - & 5.5 & 11 & 16.5 & 22 \\
\hline Corn gluten meal & 2 & 2 & 2 & 2 & 2 \\
\hline Wheat bran & 7 & 7 & 7 & 7 & 7 \\
\hline Yellow corn & 40 & 40.2 & 40.5 & 40.75 & 41 \\
\hline Corn oil & 3 & 3 & 3 & 3 & 3 \\
\hline Vit $^{2}$ and Min. $^{3}$ mix. & 2 & 2 & 2 & 2 & 2 \\
\hline Total & 100 & 100 & 100 & 100 & 100 \\
\hline \multicolumn{6}{|l|}{ Proximate analysis (\%) on DM basis } \\
\hline Dry matter $\%$ & 94.92 & 94.03 & 94.19 & 94.29 & 94.47 \\
\hline Crude Protein & 30.33 & 30.20 & 30.28 & 30.23 & 30.20 \\
\hline Ether Extract & 6.54 & 6.76 & 6.97 & 7.18 & 7.40 \\
\hline Ash & 5.38 & 5.34 & 5.30 & 5.78 & 5.74 \\
\hline Crude Fiber & 3.80 & 4.09 & 4.38 & 4.67 & 4.96 \\
\hline Nitrogen free extract & 53.95 & 53.67 & 53.07 & 52.14 & 51.70 \\
\hline $\mathrm{GE}(\mathrm{kcal} / 100 \mathrm{~g})^{4}$ & 455.07 & 455.11 & 455.23 & 453.09 & 453.19 \\
\hline $\mathrm{P} / \mathrm{E}$ ratio $^{6}(\mathrm{mg}$ crude protein $/ \mathrm{Kcal})$ & 66.65 & 66.36 & 69.14 & 69.03 & 68.87 \\
\hline \multicolumn{6}{|c|}{ 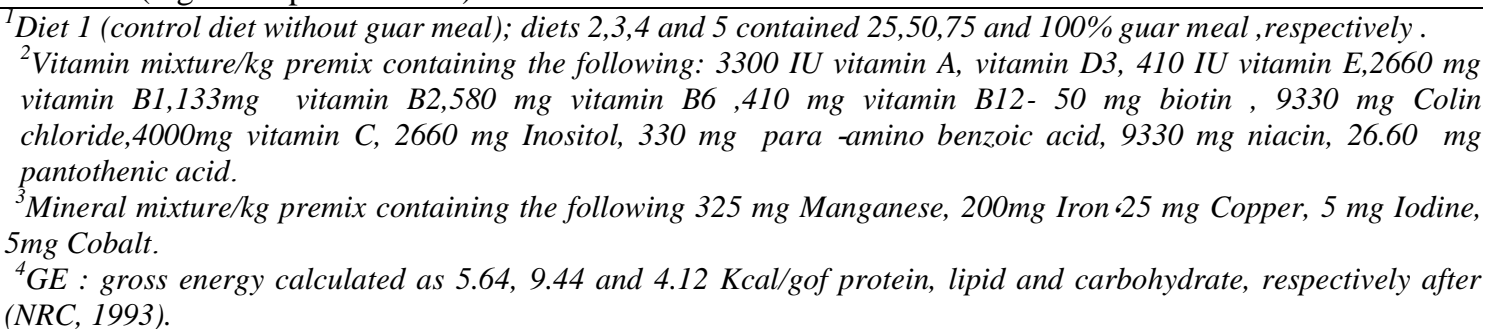 } \\
\hline
\end{tabular}

\section{Growth performance parameters:}

Total weight gain, average daily gain, specific growth rate, feed conversion ratio protein and energy utilization were calculated according to Recker, (1975) and Castell and Tiews, (1980).

1. Total gain $(\mathrm{g} / \mathrm{fish})=\left(\mathrm{W}_{\mathrm{T}}-\mathrm{W}_{\mathrm{I}}\right)$, where: $\mathrm{W}_{\mathrm{T}}$ : Final weight of fish in grams and $\mathrm{W}_{\mathrm{I}}$ : Initial weight of 1 fish in grams.

2. Average daily gain $(\mathrm{ADG} ; \mathrm{g} / \mathrm{fish} /$ day $)=$ total gain $/$ duration period.

3. Specific growth rate $(\mathrm{SGR}$, percent/day $)=100 \times\left(\ln \mathrm{W}_{\mathrm{T}}-\ln \mathrm{W}_{\mathrm{I}}\right) /$ duration period. Where: $\ln$ is the natural log.

\section{Feed and nutrient utilization parameters:}

1. Feed conversion ratio $(\mathrm{FCR})=$ dry matter intake $(\mathrm{g}) /$ total gain $(\mathrm{g})$.

2. Protein efficiency ratio $(\mathrm{PER})=$ total gain $(\mathrm{g}) /$ protein intake $(\mathrm{g})$.

3. Protein productive value $(\mathrm{PPV} \%)=\left(\mathrm{P}_{\mathrm{T}}-\mathrm{P}_{\mathrm{I}}\right) \times 100 /$ protein intake $(\mathrm{g})$, where: $\mathrm{P}_{\mathrm{T}}$ : Protein content in fish carcass at the end and $\mathrm{P}_{\mathrm{I}}$ : Protein content at the start.

4. -Energy utilization $(\mathrm{EU} \%)=\left(\mathrm{E}_{\mathrm{T}}-\mathrm{EI}\right) \times 100 /$ Energy intake $(\mathrm{kcal})$, where: $\mathrm{E}_{\mathrm{T}}$ : Energy in fish carcass (kcal) at the end and $\mathrm{E}_{\mathrm{I}}$ : Energy in fish carcass at the start.

\section{Proximate chemical analysis (\%):}

Proximate analysis (\%) and amino acid composition (g/100g) of guar meal(GM), soybean meal $(\mathrm{SBM})$ and the experimental diets were chemically analyzed to determine the percentages of dry matter 
(DM), crude protein $(\mathrm{CP}, \mathrm{N} \times 6.25)$, ether extract $(\mathrm{EE})$, crude fiber $(\mathrm{CF})$ and ash contents according to the AOAC (2000) methods. Nitrogen free extract (NFE) was calculated by differences, by deducting the sum of percentlages of moisture, CP, EE, CF and ash from 100.

Gross energy (GE) contents of the experimental diets and fish carcass were calculated by using the NRC (1993) factors of 5.64, 9.44 and $4.12 \mathrm{kcal} / \mathrm{g}$ for protein, lipid and carbohydrates, Also, amino acids composition of the tested ingredients and the experimental diets were determined by HPLC.

\section{Carcass analysis:}

At the start of the experiment, some fish samples were collected and immediately frozen and reserved for initial proximate carcass chemical composition $(\%)$. Also at the end of the experiment after blood sampling, five fish were randomly obtained from each aquarium and exposed to the chemical composition. Proximate analyses of whole body DM\%, CP\%, EE\%, and ash content \% were performed according to standard AOAC, (2000) methods.

\section{Blood parameters determination:}

At the end of the experiment, heparinized blood samples were withdrawn from fish with average final weight, for hematological and biochemical determination by using commercial kits. Heparinized blood samples of the different groups were collected from the caudal peduncle. Adequate amounts of whole blood were collected in small plastic vials containing heparin for determination of hemoglobin concentration $(\mathrm{Hb}) ;(\mathrm{g} / \mathrm{dl})$, Hematocrit $(\mathrm{Ht})$ by using commercial kits (Diamond Diagnostic, Egypt). Other blood samples were collected and then centrifuged at $3500 \mathrm{rpm}$ for $15 \mathrm{~min}$ to obtain blood plasma for determination of total protein (Gornall et al., 1949); uric acid (Schultz,1984), aspartate aminotransferase (AST) and alanine aminotransferase (ALT) (Varley,1976) using a spectrophotometer (model 5010, Germany) and commercial kits.

\section{Economic evaluation:}

Economic evaluation was calculated according to Ayyat,(1991) as the following equation: profit = Income from body weight gain - feed cost. Other overhead costs were assumed constant. Price of one $\mathrm{kg}$ of diet was 2.159 LE (Egyptian pound = 0.185 US\$) and price of selling of one $\mathrm{kg}$ fish live body weight was 10.0 LE.

\section{Statistical procedures:}

F-test and analysis of variance of treatments difference was performed according to Steel Torrie (1980). Statistical analysis was done by, ANOVA, F-test and by east significant difference (L.S.D) procedures available within the SAS (1997).

The following model was used to analyze data obtained of the experiment.

$$
1 \mathrm{Yij}=\mu+\alpha \mathrm{i}+\mathrm{e} \mathrm{ij}
$$

Where; Yij $=$ the observation of the fish with the eaten diet; $\mu=$ overall mean; $\alpha \mathrm{i}=$ the effect of $\mathrm{j}$ the effect of diet. e $\mathrm{ij}=$ random error assumed to be independently and randomly distributed.

\section{RESULT AND DISCUSSION}

\section{Chemical composition and essential amino acids contents of guar meal and soybean meal:}

Chemical compositions of GM and SBM on DM basis are presented in Table (2). Protein represents the most important nutrient in guar meal with respect to its potential as a livestock feed. Results in this table (2) reveal that guar meal contains less protein and grows energy and more ether extract and crude fiber compared to soybean meal. Mathur and Mathur, (1989) reported that the minimum crude protein percentage of guar meal is rated at $50 \%$ compared to $48 \%$ of soy bean meal. and has a higher protein solubility of $89 \%$ than soybean meal with $78 \%$. Eessential amino acids contents of GM and SBM on DM basis are presented in Table (2) reveal that guar meal contains less lysine $(0.97 \%)$ and more methionine $(1.41 \%)$ compared to soybean meal $(2.66 \%$ and $0.55 \%$, respectively) which may indicate that the use of both meals in tilapia diets could satisfy tilapia requirements from both amino acids. Furthermore, soybean meal contains high level of total essential amino acids compared to guar meal. However, guar meal has a total similar amino acid to soy bean meal. On the other hand, Mathur and Mathur (1989) reported that amino acids composition of guar meal contains Lysine $(3.22 \%)$ and methionine $(0.73 \% \%)$. 
Table (2). Proximate chemical analysis (\%) and amino acid composition (g/100g) of guar meal (GM) and soybean meal (SBM).

\begin{tabular}{lcc}
\hline Parameter & Guar meal & Soybean Meal \\
\hline Proximate analysis (\%) & & \\
Dry Matter & 93.80 & 91.15 \\
Crude protein & 42.00 & 43.12 \\
Ether extract & 5.30 & 1.49 \\
Crude Fiber & 12.70 & 7.19 \\
Ash & 5.80 & 6.23 \\
Nitrogen free extract & 34.20 & 41.97 \\
Gross energy(kcal/100g) & 427.81 & 430.19 \\
\hline Amino acids composition $(\mathrm{g} / 100 \mathrm{~g})$ & & \\
Arginine & 1.93 & 3.07 \\
Histamine & 1.18 & 1.05 \\
Isoleucine & 2.48 & 1.89 \\
Leucine & 1.60 & 3.16 \\
Lysine & 0.97 & 2.66 \\
Methionine & 1.41 & 0.55 \\
Phenylalanine & 2.89 & 2.12 \\
Threonine & 2.00 & 1.68 \\
Tryptophan & 0.52 & 0.59 \\
Valine & 2.77 & 1.96 \\
Total essential amino acids & 17.8 & 18.7 \\
\hline
\end{tabular}

\section{Amino acid composition in the experimental diets:}

The effects of dietary CP due to GM replacement levels instead of SBM on amino acid composition in the experimental diets are illustrated in Table (3). These values were calculated based on their ingredients levels , according to NRC (1993). Amino acid compositions in the experimental diets were differed among all treatments. So, some of them were sufficient to cover Nile tilapia requirements and others were not specially the essential amino acids, lysine and methionine in all diets.

Table (3). Amino acid composition of the experimental diets and amino acid requirements of Nile tilapia, Oreochromis niloticus, L., (g100 g -1diet).

\begin{tabular}{lcccccc}
\hline \multirow{2}{*}{$\begin{array}{l}\text { Indispensable amino } \\
\text { acid }\end{array}$} & \multirow{2}{*}{ Required $^{1}$} & \multicolumn{5}{c}{ Diet No. $^{2}$} \\
\cline { 2 - 6 } Arginine & 1.60 & 1.63 & 1.65 & 1.68 & 1.7 & 1.72 \\
Histidine & 0.65 & 0.61 & 0.73 & 0.8 & 0.89 & 0.97 \\
Isoleucine & 1.18 & 1.05 & 1.07 & 1.09 & 1.1 & 0.97 \\
Leucine & 1.29 & 2.07 & 2.09 & 2.12 & 2.48 & 2.17 \\
Lysine & 1.95 & 1.55 & 1.58 & 1.6 & 1.63 & 1.65 \\
Methionine & 1.02 & 0.55 & 0.82 & 0.82 & 0.83 & 0.84 \\
Phenyalanine & 1.43 & 1.19 & 1.27 & 1.35 & 1.44 & 1.52 \\
Thereonine & 1.43 & 0.99 & 1.02 & 0.87 & 0.81 & 0.76 \\
Tryptophan & 0.32 & 0.60 & 0.63 & 0.59 & 0.58 & 0.58 \\
Valine & 1.06 & 1.24 & 1.25 & 1.27 & 1.29 & 1.31 \\
Total & 11.9 & 11.5 & 12.1 & 12.2 & 12.8 & 12.5 \\
\hline
\end{tabular}

${ }^{T}$ From Santiago and Lovell (1988)

${ }^{2}$ Diet 1 (control diet without guar meal); diets 2,3,4 and 5 contained 25,50,75 and 100\% guar meal, respectively.

\section{Growth performance:}

The effects of GM replacement levels instead of SBM protein on growth performance of Nile tilapia were illustrated in Table (4). Growth performance measured as final weight (g/fish) differed among all treatments significantly $(\mathrm{P} \leq 0.01)$. The best significant final weight $(18.76 \mathrm{~g} / \mathrm{fish})$, total weight gain (17.95g/fish), ADG (0.21 g/fish /day) and SGR (3.73\%/day)were obtained by fish fed diet 3 . The lowest final weight (11.44 g/fish), total weight gain (10.61g/fish), ADG (0.13g/fish /day) and SGR (3.12\%/day) 
were obtained with diet 5. Replacing of SBM by GM protein up to 50\% in tilapia diets had higher significant $(\mathrm{P} \leq 0.01)$ effect on growth performance, while the highest replacing levels (75 or $100 \%)$, significantly $(\mathrm{P} \leq 0.01)$ reduced. The present results exhibited that guar meal protein can replace soy bean protein up to $50 \%$ in practical diets of mono sex Nile tilapia. These findings are in agreement with the results of AI-Hafedh and Siddiqui,( 1998) who suggest that effective replacement of fish meal protein by guar meal protein up to the level of $50 \%$ is possible in tilapia practical diets without any adverse effects on growth and feed conversion ratio.

Table (4). Effect of partial and complete replacement of SBM protein by GM protein on growth performance of Nile tilapia, Oreochromis niloticus, L.

\begin{tabular}{|c|c|c|c|c|c|}
\hline \multirow[b]{2}{*}{ Diet No. ${ }^{*}$} & \multicolumn{2}{|c|}{ Body weight } & \multirow[b]{2}{*}{$\begin{array}{l}\text { Total weight } \\
\text { gain (g/fish) }\end{array}$} & \multirow[b]{2}{*}{$\begin{array}{c}\text { Average daily } \\
\text { gain (ADG) } \\
\text { (g/fish/day) }\end{array}$} & \multirow{2}{*}{$\begin{array}{c}\text { Specific } \\
\text { growth rate } \\
\text { (SGR) } \\
\text { (\%/day) }\end{array}$} \\
\hline & $\begin{array}{c}\text { Initial } \\
\text { (g/fish) }\end{array}$ & $\begin{array}{c}\text { Final } \\
\text { (g/fish) }\end{array}$ & & & \\
\hline 1 & 0.83 & $16.49^{c}$ & $15.66^{\mathrm{c}}$ & $0.19^{c}$ & $3.57^{b}$ \\
\hline 2 & 0.83 & $17.38^{\mathrm{b}}$ & $16.55^{\mathrm{b}}$ & $0.20^{\mathrm{b}}$ & $3.62^{\mathrm{b}}$ \\
\hline 3 & 0.82 & $18.76^{\mathrm{a}}$ & $17.95^{\mathrm{a}}$ & $0.21^{\mathrm{a}}$ & $3.73^{\mathrm{a}}$ \\
\hline 4 & 0.83 & $14.22^{\mathrm{d}}$ & $13.40^{\mathrm{d}}$ & $0.16^{\mathrm{d}}$ & $3.39^{c}$ \\
\hline 5 & 0.83 & $11.44^{\mathrm{e}}$ & $10.61^{\mathrm{e}}$ & $0.13^{\mathrm{e}}$ & $3.12^{\mathrm{d}}$ \\
\hline L.S.D $(\mathrm{P}<0.01)^{* *}$ & - & 0.238 & 0.245 & 0.012 & 0.079 \\
\hline
\end{tabular}

\section{Feed and nutrient utilization:-}

Results of Table (5) indicated that there were significant differences in feed intake $(\mathrm{P} \leq 0.01)$ between all treatments. The highest value of feed intake was obtained by fish fed on diet 5 which containing 100 $\% \mathrm{GM}$, whereas the lowest one was recorded for the control.

Table (5). Effect of partial and complete replacement of SBM protein by GM protein on feed and nutrient utilization parameters of Nile Tilapia, $O$. niloticus.

"Diet 1 (control diet without guar meal); diets 2, 3, 4 and 5 contained 25, 50, 75 and 100\% guar meal, respectively.

\begin{tabular}{lccccc}
\hline Diet No. & $\begin{array}{c}\text { Feed } \\
\text { intake } \\
(\mathrm{gm} / \mathrm{fish})\end{array}$ & $\begin{array}{c}\text { Feed } \\
\text { conversion } \\
\text { ratio (FCR) }\end{array}$ & $\begin{array}{c}\text { Protein efficiency } \\
\text { ratio (PER) }\end{array}$ & $\begin{array}{c}\text { Protein } \\
\text { productive } \\
\text { value (PPV\%) }\end{array}$ & $\begin{array}{c}\text { Energy } \\
\text { Utilization } \\
(\text { EU\%) }\end{array}$ \\
\hline D 1 & $30.77^{\mathrm{b}}$ & $1.97^{\mathrm{c}}$ & 1.52 & $28.55^{\mathrm{b}}$ & $18.31^{\mathrm{ab}}$ \\
$\mathrm{D} 2$ & $32.11^{\mathrm{ab}}$ & $1.94^{\mathrm{c}}$ & 1.59 & $27.70^{\mathrm{b}}$ & $17.84^{\mathrm{b}}$ \\
D 3 & $30.24^{\mathrm{b}}$ & $1.69^{\mathrm{d}}$ & 1.96 & $33.57^{\mathrm{a}}$ & $21.49^{\mathrm{a}}$ \\
D 4 & $33.49^{\mathrm{a}}$ & $2.50^{\mathrm{b}}$ & 1.45 & $22.37^{\mathrm{c}}$ & $14.32^{\mathrm{c}}$ \\
D 5 & $33.94^{\mathrm{a}}$ & $3.11^{\mathrm{a}}$ & 1.26 & $17.40^{\mathrm{d}}$ & $11.22^{\mathrm{d}}$ \\
L.S.D (P<0.01) & $2.17^{* *}$ & 0.141 & 0.795 & 1.515 & 0.872 \\
\hline ***ans followed by different letters in the same column differ significantly but the same latters are not significantly \\
according LSD method at alfa (0.01).
\end{tabular}

The worst value (3.11) of feed conversion ratio (FCR) was obtained by the diet 5 followed by diet 4 and the control diet. The best FCR value (1.69), PER (1.96) and PPV (33.57) were observed with diet 3 which containing $50 \%$ GM instead of SBM. The same trend was obtained with the energy utilization (EU $\%$ ). The highest feed intakes (33.49 and $33.94 \mathrm{~g} / \mathrm{fish}$ ) were obtained for fish fed diets 4 and 5 , respectively. The best Feed Conversion Ratio (FCR) was obtained for fish fed diets No .3. However, the highest replacing levels (75 or 100\%) significantly adversed FCR (Table 5). The results showed that there was non-significant differences $(\mathrm{P} \geq 0.01)$ in protein efficiency ratio (PER) for all fish fed with the test diets. However, replacement with 75 and $100 \%$ GM levels significantly reduced $(\mathrm{P} \leq 0.01)$ protein productive value (PPV) and energy utilization (EU). A combination of several plant protein sources with 
different amino acid and protein levels was found to be most suitable for incorporation in Oreochromis niloticus diets (Jackson et al. 1982). In this connection the previous results, AI-Hafedh and Siddiqui (1998) showed that Nile tilapia fish fed diets contained either $25 \%$ or $50 \%$ dietary guar seed meal replacer for fish meal had the same FCR and were not significantly different. They concluded that guar meal could be used up to the $50 \%$ inclusion rate of fish meal protein in Nile tilapia diets without significant effect on FCR.

\section{Fish whole body composition:}

Averages of whole body composition of Nile tilapia $O$. niloticus including dry matter (DM), crude protein (CP), ether extract (EE), ash content as percentage of (DM) and energy contents (kcal GE/kg DM) as affected with the dietary treatments at the start and end of the experimental period are presented in Table (6). Results revealed that DM, CP, EE, Ash and energy contents of tilapia whole bodies were 23.70, $55.65,20.65,23.25 \%$ and $509.57 \mathrm{Kcal} \mathrm{GE} / 100 \mathrm{~g} \mathrm{DM}$ at the start of the experiment, respectively. Results revealed that DM, CP, EE, and energy contents in tilapia whole bodies at the end of the experimental period were higher in the treatment groups compared with the corresponding values at the experimental start except for Ash content. At the end of the experimental period, groups fed on the 50\% treated guar meal group showed higher DM, CP, EE contents and energy content in the DM of whole bodies compared to the 75 and $100 \%$ guar meal groups. On the other hand, the 75 and $100 \%$ guar meal group showed significantly $(\mathrm{P} \leq 0.01)$ higher ash content compared to the other treatment groups. Ether extract, ash and energy contents were not significantly different $(\mathrm{P} \geq 0.01)$ among all experimental diets and control diet. There were no significant differences $(\mathrm{P} \geq 0.01)$ in dry matter and protein contents between fish fed $75 \%$ GM (D4) and $100 \%$ GM (D5). The results of El-Saidy and Saad (2008). Soltan et al. (2008); El-Saidy et al. (2009); Abd el-Hakim et al, (2010). and Mabrouk et al. (2012) exhibited the same trend.

These results are in agreement with the findings of Ali (2004) who reported that incorporation of $14.80 \%$ of Jojoba meal (in replacement of $25 \%$ of soybean meal protein) in Nile tilapia diets increased DM, CP and EE contents in whole fish bodies compared to higher levels (50\%or 75\%) of Jojoba meal in replacement of soybean protein .

Table (6). Effect of partial and complete replacement of SBM protein by GM protein on carcass composition of Nile Tilapia, $O$. niloticus .

\begin{tabular}{|c|c|c|c|c|c|}
\hline \multirow[t]{2}{*}{ Diet No." } & \multirow{2}{*}{$\begin{array}{l}\text { Dry Matter } \\
\%\end{array}$} & \multicolumn{3}{|c|}{$\%$ On dry matter basis } & \multirow{2}{*}{$\begin{array}{l}\text { Energy Conten } \\
(\mathrm{kcal} / 100 \mathrm{~g})\end{array}$} \\
\hline & & Crude Protein & Ether extract & Ash & \\
\hline \multicolumn{6}{|c|}{ At start of the experiment: } \\
\hline & 23.70 & 55.65 & 20.65 & 23.25 & 509.57 \\
\hline \multicolumn{6}{|c|}{ At end of the experiment: } \\
\hline D 1 & $28.68^{\mathrm{ab}}$ & $58.60^{\mathrm{ab}}$ & 23.47 & 17.93 & 552.30 \\
\hline D 2 & $28.00^{\mathrm{b}}$ & $57.41^{\mathrm{b}}$ & 23.48 & 19.11 & 545.68 \\
\hline D 3 & $28.78^{\mathrm{a}}$ & $58.85^{\mathrm{a}}$ & 23.63 & 17.52 & 555.22 \\
\hline D 4 & $28.57^{\mathrm{ab}}$ & $58.36 \mathrm{ab}$ & 23.36 & 18.28 & 549.90 \\
\hline D 5 & $28.00^{\mathrm{b}}$ & $57.41^{\mathrm{b}}$ & 23.48 & 19.11 & 545.68 \\
\hline L.S.D $(\mathrm{P}<0.01)^{* *}$ & 0.730 & 1.401 & 0.909 & 2.19 & 15.97 \\
\hline
\end{tabular}

\section{Blood hematological and biochemical parameters:}

The effects of dietary GM replacement levels instead of SBM protein on blood hematological and biochemical parameters of Nile tilapia fingerlings are illustrated in Table (7). Hematological parameters measured as $\mathrm{HB}(\mathrm{g} / \mathrm{dl})$ and $\mathrm{HT}(\%)$ differed among all treatments significantly $(\mathrm{P} \leq 0.01)$. The best significant $\mathrm{HB}(5.81 \mathrm{~g} / \mathrm{dl}), \mathrm{PCV}(20.80 \%)$ and total protein $(\mathrm{g} / \mathrm{dl})$ was obtained by fish fed diet 3 . Also, the best significant HT (25.97\%) was obtained by fish fed diet 3 where $50 \%$ GM protein replaced SBM protein followed by fish fed on diet 5, where fish fed diet with $100 \%$ GM protein instead of SBM protein, respectively. But there was significant effect of PCV (\%) between treatments. Biochemical parameters measured as total protein $(\mathrm{g} / \mathrm{dl})$ didn't differ significantly between treatments. Hepatic function (AST and ALT) differed among all treatments significantly ( $\mathrm{P} \leq 0.01)$. The highest significant 
AST and ALT (38.44 and 28.32 U/L) were obtained by fish fed diet 5. Kidney function creatinine, urea and uric acid $(\mathrm{mg} / \mathrm{dl})$ were measured in blood samples. Creatinine $(\mathrm{mg} / \mathrm{dl})$ didn't differ significantly between treatments, while and urea and uric acid $(\mathrm{mg} / \mathrm{dl})$ has significant effect $(\mathrm{P} \leq 0.01)$ between treatments. The highest significant uric acid $(1.93 \mathrm{mg} / \mathrm{dl})$ was obtained by fish fed diet 5 follwed by diet 4 $(1.90 \mathrm{mg} / \mathrm{dl})$. Barraza et al. (1991) reported that the hematological variables, hematocrit and hemoglobin, are important measures as indicators for the rate of hemoglobin synthesis to red cell formation, and erythrocyte sedimentation rate. The estimations of serum enzyme activities of AST and ALT are taken as an indication of the amount of liver damage, as the elevated serum enzyme levels might be related to the degree of liver injury. Liver disease causes an increase in some serum enzymes by blocking their elimination into the blood Barraza et al. (1991) and Soltan et al. (2008)

Table (7). Effect of partial and complete replacement of SBM protein by GM protein on blood hematological and biochemical parameters of Nile tilapia (O. niloticus).

\begin{tabular}{lccccccccc}
\hline & & & & \multicolumn{3}{c}{ Tepatic function } & \multicolumn{3}{c}{ Kidney function } \\
Diet No. & $\begin{array}{c}\mathrm{HB}^{2} \\
(\mathrm{~g} / \mathrm{dl})\end{array}$ & $\begin{array}{c}\mathrm{HT}^{3} \\
(\%)\end{array}$ & $\begin{array}{c}\mathrm{PCV}^{4} \\
(\%)\end{array}$ & $\begin{array}{l}\text { Total } \\
\text { protein } \\
(\mathrm{g} / \mathrm{dl})\end{array}$ & $\begin{array}{l}\mathrm{AST}^{5} \\
(\mathrm{U} / \mathrm{L})\end{array}$ & $\begin{array}{l}\mathrm{ALT}^{6} \\
(\mathrm{U} / \mathrm{L})\end{array}$ & $\begin{array}{l}\text { Creatinine } \\
(\mathrm{mg} / \mathrm{dl})\end{array}$ & $\begin{array}{l}\text { Urea } \\
(\mathrm{mg} / \mathrm{dl})\end{array}$ & $\begin{array}{l}\text { Uric } \\
\text { Acid } \\
(\mathrm{mg} / \mathrm{dl})\end{array}$ \\
\hline D1 & $5.61^{\mathrm{ab}}$ & $25.31^{\mathrm{b}}$ & $20.12^{\mathrm{ab}}$ & $4.76^{\mathrm{b}}$ & $37.19^{\mathrm{b}}$ & $26.39^{\mathrm{b}}$ & 0.43 & $4.72^{\mathrm{c}}$ & $1.84^{\mathrm{ab}}$ \\
D2 & $5.67^{\mathrm{ab}}$ & $25.65^{\mathrm{ab}}$ & $20.49^{\mathrm{a}}$ & $5.27^{\mathrm{a}}$ & $36.75^{\mathrm{c}}$ & $25.63^{\mathrm{c}}$ & 0.40 & $4.67^{\mathrm{c}}$ & $1.77^{\mathrm{b}}$ \\
D3 & $5.81^{\mathrm{a}}$ & $25.97^{\mathrm{a}}$ & $20.80^{\mathrm{a}}$ & $5.44^{\mathrm{a}}$ & $36.39^{\mathrm{c}}$ & $25.03^{\mathrm{c}}$ & 0.38 & $4.45^{\mathrm{c}}$ & $1.70^{\mathrm{b}}$ \\
D4 & $5.47^{\mathrm{ab}}$ & $26.27^{\mathrm{a}}$ & $19.65^{\mathrm{b}}$ & $4.33^{\mathrm{c}}$ & $38.14^{\mathrm{a}}$ & $23.14^{\mathrm{d}}$ & 0.48 & $5.68^{\mathrm{b}}$ & $1.90^{\mathrm{a}}$ \\
D5 & $5.31^{\mathrm{b}}$ & $26.03^{\mathrm{a}}$ & $17.62^{\mathrm{c}}$ & $3.75^{\mathrm{d}}$ & $38.44^{\mathrm{a}}$ & $28.32^{\mathrm{a}}$ & 0.51 & $6.25^{\mathrm{a}}$ & $1.93^{\mathrm{a}}$ \\
LSD (P<0.01)7 & 0.403 & 0.456 & 0.735 & 0.403 & 0.380 & 0.642 & 0.151 & 0.353 & 0.274 \\
\hline
\end{tabular}

${ }^{T}$ Diet 1 (control diet without Guar meal); diet 2, 3, 4 and 5 contained 25, 50, 75 and 100\% Guar meal, respectively.

${ }^{2} \mathrm{HB}=$ Hemoglobin $/ \mathrm{dl} ;{ }^{3} \mathrm{HT}=$ Hematocrit,$\% ;{ }^{4} \mathrm{PCV}=$ Packed cell value; ${ }^{5} \mathrm{ALT}=$ aspartate aminotransferase $;$ and ${ }^{6} \mathrm{AST}=$ alanine aminotransferase

${ }^{7}$ Means followed by different letters in the same column differ significantly but the same latters are not significantly according LSD method at alfa (0.01).

From the above discussion, it may be concluded that the reduced growth performance of fish-fed diets 4 and 5 might be related to saponins substances and ant nutrient content in GM. The large amounts of saponin content of guar seed (up to $13 \% \mathrm{DM}$ ) could have both anti-nutritionals effect and a positive antimicrobial activity (Hassan et al., 2010). However, fish fed a plant-based diet may benefit from a stronger immune response to certain toxins since several plant NSPs (non-starch polysaccharides) are known to stimulate its immune system (Nordmo et al., 1995; Skjermo et al., 2006). Mode of action of antibacterial activity of saponins against both gram-negative and gram-positive bacteria is not yet clear. Avato et al., (2006) noted that the aglycone part of the saponin is the antibacterial determinant suggesting that the sugar moiety is not important for the antimicrobial efficacy, while another study reported that saponins hydrolysed by bacterial enzymes to its corresponding aglycone resulted in decreased antibacterial activity (Mandal et al., 2005). The significantly faster growth of fish-fed diets 2 and 3 (25\% and $50 \% \mathrm{GM}$ ) might be due to the fact that the essential amino acid composition was well balanced and the levels of ANFs in diet 3 were below the level that induces toxic elects in Nile tilapia. The results of the present study indicated that up to $50 \%$ of GM in diet Nile tilapia can be included without affecting the growth and nutrient utilization. However, studies are underway to investigate the possibility of a higher dietary inclusion level of GM after applying deferent processing techniques to detoxify or reduce the ant nutrient content.

\section{Economic evaluation:}

Calculations of economic efficiency of the tested diets based on the cost of feed, decrease in feed cost $(\%)$ and relative to control $(\%)$ were shown in Table (8). At the $100 \%$ level of GM protein instead of SBM protein, fish could be produced cheaper than fish fed on the control and other diets because it was the cheapest diet between them $(4186.7 \mathrm{LE} /$ ton). The relative percentages of feed cost/ control were 97.44, 94.84, 92.26 and $89.69 \%$ for D2, D3, D4 and D5, respectively compared to control diet (D1). Moreover, decrease in feed cost/ control was 2.56, 5.16, 7.74 \% and 10.31 for D2, D3, D4 and D5 , respectively. These results indicate that the effect of replacement different levels of GM instead of SBM improved diet cost according to the replacement level. These results indicate that incorporation of guar meal to replace $50 \%$ of soybean meal protein resulted in the lowest revenues. In general, results in Table (8) show that incorporation of guar meal to replace $50 \%$ of soybean meal protein improved the economical efficiency of Nile tilapia due to improvement in body weight. Similarly Soltan et al. (2008) in Nile tilapia. In this concern, Abd El-Hakim et al. (2010) and Mabrouk et al. (2012) reported that the 
highest economical efficiency of tilapia was obtained using diets containing $25 \%$ Jojoba meal in replacement with soybean meal protein. They added that increasing level of Jojoba meal above $25 \%$ decreased the economical efficiency. Feed cost is considered to be the highest recurrent cost in aquaculture, often ranging from 30 to $60 \%$, depending on the intensity of the operation. Reduction in feed costs either through diet development, improved husbandry or other direct or indirect means is lead to, decreases the total production investment and increased the net return (Lovell, 1989).

Table (8). Effect of partial and complete replacement of SBM protein by GM protein on carcass composition of Nile Tilapia, $O$. niloticus.

\begin{tabular}{lccccc}
\hline $\begin{array}{c}\text { Diet } \\
\text { No. }\end{array}$ & $\begin{array}{c}\text { Feed cost, LE / } \\
\text { ton }\end{array}$ & $\begin{array}{c}\text { Relative to } \\
\text { control } \%\end{array}$ & $\begin{array}{c}\text { Decrease in feed } \\
\text { cost } \%\end{array}$ & Total return & $\begin{array}{c}\text { Economic } \\
\text { efficiency }\end{array}$ \\
\hline D1 & 4668.2 & 100.00 & 0.00 & 120.54 & 371.70 \\
D2 & 4548.8 & 97.44 & 2.56 & 129.19 & 389.63 \\
D3 & 4427.45 & 94.84 & 5.16 & 143.33 & 423.72 \\
D4 & 4307.075 & 92.26 & 7.74 & 97.78 & 320.09 \\
D5 & 4186.7 & 89.69 & 10.31 & 70.19 & 258.77 \\
\hline
\end{tabular}

${ }^{7}$ Diet 1 (control diet without Guar meal); diet 2, 3, 4 and 5 contained 25, 50, 75 and 100\% Guar meal, respectively.

\section{CONCLUSION}

Finally, the results of the present experiment concluded that substitution 50\% of dietary SBM protein with $50 \%$ of dietary GM protein had the best effect on Nile tilapia (Oreochromis niloticus) performances.

\section{REFERENCES}

Abd El-Hakim,N.F.; M.E. Lashin; H.D. Tonsy;S.H. Mohmoud and M.K. Sayed (2010). Effect of replacing soybean meal protein with jojoba seed meal in diets ofgrowing mono-sex Nile tilapia (Oreochormis niloticus) on growthperformance and nutrient utilization. Egypt J. Aquat. Biol. \& Fish., 14(1): 13-26.

AI-Hafedh, Y.S. and A.Q. Siddiqui (1998). Evaluation of guar seed as a protein source in Nile tilapia, Oreochromis niloticus (L.), practical diets. Aquaculture Research, 29(10): 703-708.

Ali, A. El-Makarem (2004). "Nutritional studies on fish performance under intensive production conditions." Ph.D. Thesis, Animal Production Dep., Fac. Agric, Ain Shams Univ.

AOAC (2000). Association of Official Analytical Chemists. Official methods of analysis, 16th Edition, AOAC, Arlington, VG., USA.

Avato, P.; R. Bucci; A. Tava; C. Vitali; A. Rosato; Z. Bialy (2006). Antimicrobial Activity of saponins from Medicago spp.: Structure-activity relationship. Phytotherapy Research, 20: 454-457.

Ayyat, M.S. (1991). Growth, feed efficiency and carcass traits of growing rabbits as affected by levels of dietary protein and sulphur amino acids. Egyptian Journal of Rabbit Science, 1(1): 1-12.

Barraza, M.I.; C.E. Coppock; K.N. Brooks; D.L. Wilks; R.G. Saunders and G.W. Latimer (1991). Iron sulfate and feed pelleting to detoxify free gossypol in cottonseed diets for dairy cattle. J. Dairy. Sci., 74: 3457-3467.

Castell, J.D. and K. Tiewes (Editor) (1980). Report of the EIFAC, IUNS and ICES Working Group on the standardization of Methodology in Fish Research, Hamburg, FRG,212-23 March, 1979. IFAC Tech. Pap. (3) 24.

Cheng, Z.J. and R.W. Hardy (2002). Apparent digestibility coefficients and nutritional value of cottonseed meal for rainbow trout (Oncorhynchus mykiss). Aquaculture, 212: 361-372. 


\section{Labib et al.}

Collins, S.A.; M. Overland; A. Skrede and M.D. Drew (2013). Effect of plant protein sources on growth rate in salmonids: Meta-analysis of dietary inclusion of soybean, pea and canola/rapeseedmeals and protein concentrates. Aquaculture, 400: 85-100.

Conner, S. (2002). Characterization of guar meal for use in poultry rations. Ph.D. Dissertation. Texas A\&M University, College Station, TX.

El-Saidy, D.M.S.D.; M.M. Gaber and A.S. Abd-Elshafy (2005). Evaluation of cluster bean meal Cyamposistetragonoloba as a dietary protein source for common carp Cyprinuscarpio L. J. World Aquacult. Soc., 36 (3): 311-319.

El-Saidy, D.M.S.D.; S.H. Mahmoud; M.A. El-Garhy and H.D.Tonsy ( 2009).Nutrition evaluation of sesame seed meal, Sesamum indicum (L.) as alternative protein source in diets of juvenile mono-sex Nile tilapia(Oreochromis niloticus). Egypt. J. Aquat. Biol. \& Fish., 13(1): 93-106.

El-Saidy, D.M.S.D.; and A. Saad (2008). Evaluation of cow pea seed meal, Vigna sinensis, as a dietary protein replacer for Nile tilapia(Oreochromis niloticus (L.) fingerlings. J. worl. Aqua. Soc., 39(5): 636-645.

Francis, G.; H.P. Makkar and B.K. Becker (2001). Antinutritional factors present in plant-Derived alternate fish feed ingredients and their effects in fish. Aquaculture, 199: 197-227.

Garg, S.K.; A. Kalla and A. Bhatnagar (2002). Evaluation of raw and hydrothermically processed leguminous seeds as supplementary feed for the growth of two Indian major carp species. Aquacult. Res., 33(3): 151-163.

Golterman, H.L. (1977). Sediments as a source of phosphate for algal growth. In: Interactions Between Sediments and Freshwater (Golterman H L, ed.). Dr. W. Junk Publisher, The Hague., 286-293.

Gornall A.G.; C.J. Bardawill and M.M. David (1949). Determination of serum proteins by means of the biuret reaction. J. Biol. Chem., 177: 751-66.

Gowda, N.K.S.; J.V. Ramana; C. Prasad and S. Khub Singh (2004). Micronutrient content of certain tropical conventional and unconventional feed resources of Southern India. Trop. Anim. Health Prod., 36 (1): 77-94.

Gutierrez, O.; C.A.L. Zhang; J.B. Cartwright; Carey and Bailey (2007).Use of guar by-products in high production laying hen diets. Poult. Sci., 86: 1115-1120.

Hardy, R.W. (2010). Utilization of plant proteins in fish diets: effects of global demand and supplies of fishmeal. Aquaculture Research, 41: 770-776.

Hassan, S.M.; J.A. Haq; A.L ByrdBerhow; C.A. Cartwright and Bailey (2010). Haemolytic and antimicrobial activities of saponin-rich extracts from guar meal. Food Chem., 19: 600-605.

Jackson, A.J.; B.S. Capper and A.J. Matty (1982). Evaluation of some plant proteins in complete diets for tilapia Sarotherodon mossambicus. Aquaculture, 27: 97-109.

Lee J.T.; B. Lee; D. Shin; S.S. Kwak and J.D. Bahk (2002) Carnitine uptake by AGP2 in yeast Saccharomyces cerevisiae is dependent on Hog1 MAP kinase pathway. Mol Cells, 13 (3): 407-412.

Lee, J.T.; S. Connor-Appleton; A.U. CA.; Haq; A.L. Cartwright and Bailey (2004). Quantitative measurement of negligible trypsin inhibitor activity and nutrient analysis of guar meal fractions. J. Agric. Food Chem., 52: 6492-6495

Lovell, R.T. (1989). Nutrition and feeding of fish Van. Nostrand Reinhold, New York, NY.

Mabrouk, H.A.; E.M.H. Labib and M.A. Zaki (2012). Nutritional studies on partial and total replacement of Fishmeal by Jojoba meal (Simmondsia chinensis) in Nile tilapia Oreochromis niloticus) Fingerlings diets. Available online at www.sciencedirect.com, ICAAA 2012: July 23-24, 2012, Singapore.

Mandal, P.; S.P. Sinhababu and N.C. Mandal (2005) Antimicrobial activity of saponins from Acacia auriculiformis. Fitoterapia, 76: 462-465.

Mathur, O.P. and C.S. Mathur, (1989). Feeding of protected protein and urea supplementation for enhanced growth and feed utilization in Magra lambs. Indian J. Anim. Nutr., 6(3): 274-278. 
Nordmo, R.; J.M. Holth and B.O. Gabrielsen (1995). Immunostimulating effect of alginate feed in Atlantic salmon (Salma salar L.) challenged with Aeromonas salmonicida. Molecular Marine Biology and Biotechnology 4, 232-235.

NRC (1993). Nutrient Requirements of Fish. National Research Council. National Academy Press, Washington D.C., 114 pp.

Recker, W.E (1975) .Computation and interpretation of biological statistics of fish population. Fish Res. Res. Board Can. Bull., 191.

Salze, G.; E.,McLean; P.R. Battle; S.M.H. Chwarz, and S.R. Craig (2010). Use of soy protein concentrate and novel ingredients in the total elimination of fish meal and fish oil in diets for juvenile cobia, Rachycentron canadum. Aquaculture, 298: 294-299.

Santiago, C.B. and R.T. Lovell (1988). Amino acid requirements for growth of Nile tilapia. J. Nut., 188: $1540-1546$.

SAS (1997). SAS/STAT Guide for personal computer. SAS Inst. Cary, N.C. (ISBN: 3-540-650148.Statistical Package for the Social Sciences, SPSS,USA.

Schultz, A. (1984). "Uric acid." In: Kaplan, A. , Clin. Chem., Toronto. Princeton, pp. 418: 1261-1266.

Skjermo, J.; T.R. Storseth; K. Hansen; A. Handa and G. Oie (2006). Evaluation of b-(1-N3, 1-N6)glucans and high-Malginate used as immunostimulatory dietary supplement during first feeding and weaning of Atlantic cod (Gadus morhua L.). Aquaculture, 261: 1088-1101.

Slawski, H.; F. Nagel; K. Wysujack; D.T. Balke; P. Franz and C. Schulz (2013). Total fish meal replacement with canola protein isolate in diets fed to rainbow trout (Oncorhynchus mykiss W).Aquaculture Nutrition, 19: 535-542.

Soltan, M.A.; M.A. Hanafy and M.I.A.Wafa (2008). Effect of Replacing Fish Meal by a Mixture of Different Plant Protein Sourcesin Nile Tilapia (Oreochromis niloticus L.) Diets . Global Veterinaria, 2 (4): $157-164$.

Steel, R.G. and Torrie (1980). Principles and procedures of statistics 2nd ed. McGraw Hill, New York, U.S.A.

Van den Ingh, T.S.G.A.M.; Å. Krogdahl; J.J. Olli; H.G.C.J.M. Hendriks and J.G.J.F. Koninkx (1991). Effects of soybean-containing diets on the proximal and distal intestine in Atlantic salmon (Salmo salar): a morphological study. Aquaculture, 94: 297-305.

Varley, V. (1976). Parcical clinical Biochemisstry. 4th Edition, Newdelhi, India. Etal.

Zhou, Q.C. and Y.R. Yue (2010). Effect of replacing soybean meal with canola meal on growth,feed utilization and haematological indices of juvenile hybrid tilapia, Oreochromis niloticus $\times$ reochromis aureus. Aquaculture Research, 41: 982-990. 
دراسات غذائية على الإستبال الجزئي والكلي لمسحوق فول الصويا بكسب الجوار في علاثق أسماك البلطى

النيلى.

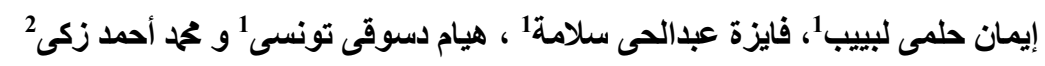

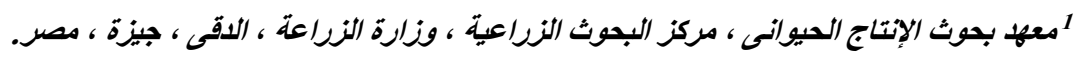

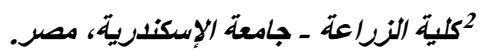

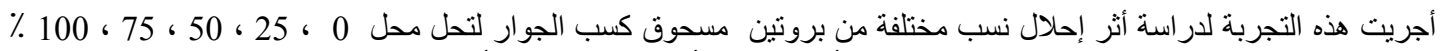

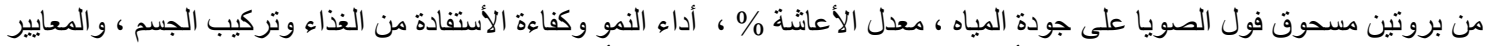

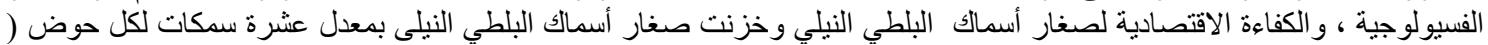

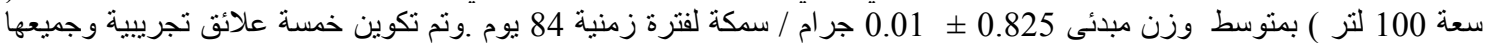

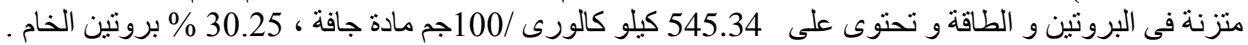

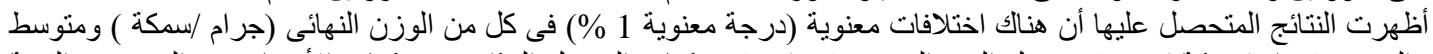

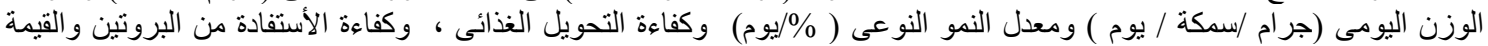

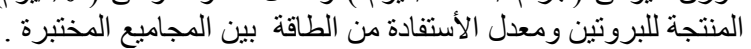

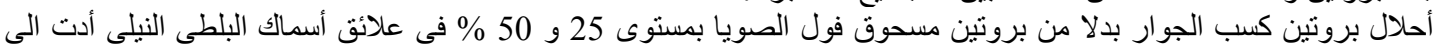

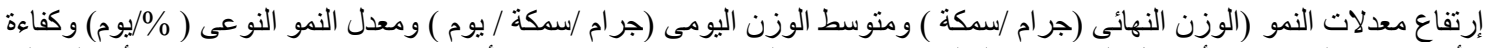

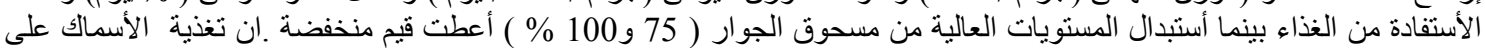

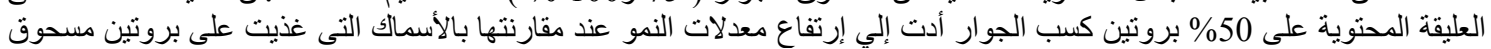

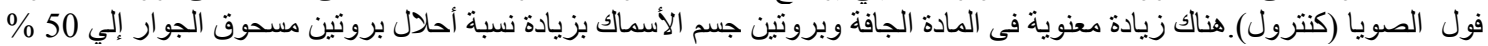

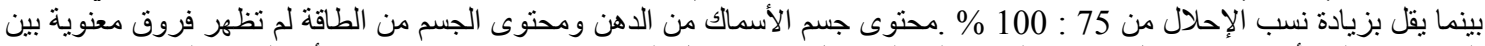

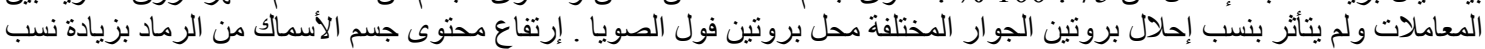

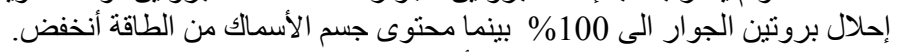

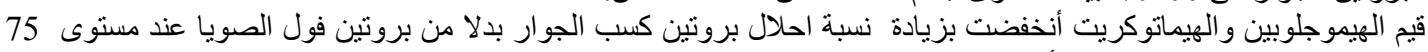

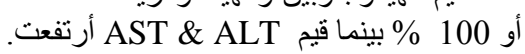

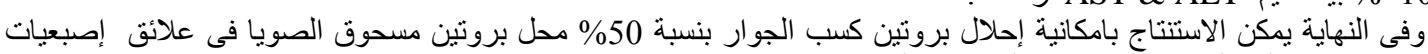
البلطى النيلى بدون أى تأثيرات ضارة على أداء النمو أومعدلات الاستفادة الغذائية. 